\title{
Maps showing distribution of dissolved solids and dominant chemical type in ground water, Basin and Range province, Idaho
}

by

Thomas H. Thompson and Richard Chappell

\section{Introduction}

This map report is one of a series of geologic and hydrologic maps of States in the Basin and Range Province. These map reports contain information on ground-water hydrology, ground-water quality, surface distribution of selected rock types, data on tectonic conditions, areal geophysical data, Pleistocene lakes and marshes and natural resources. This information is the basis tor a summary report that characterizes the Basin and Range Province. The geologic and hydrologic characterization will be used to evaluate the Province for prospective regions for further study relative to isolation of high-level radioactive waste. (Bedinger, Sargent and Reed, 1984). 


\section{Chemical quality of ground water}

Ground-water quality in the Basin and Range Province of Idaho was characterized by dissolved-solids concentration and dominant anions and cations in solution. Water-quality information was compiled from the U.S. Geological survey waterquality files (WATSTORE), published reports of the U.S. Geological Survey, and the Idaho Department of Water Resouurces.

The data on dissolved-solids concentration and water-quality type were plotted and their distributions mapped in the basin-fill deposits from the data compiled for samples collected from nongeothermal springs and wells of less than 501 feet in depth. In areas for which data were not compiled, other data sources and published reports were consulted where available. In lieu of data, the parameters in the basin-fill were estimated from the position in the ground-water flow system and the lithology of the adjacent bedrock. Data from wells greater than 500 feet in depth are included as supplemental data, but are not used in mapping dissolved-solids concentration or water-quality type. Data from wells greater than 500 feet in depth are not reflected in the mapped areas where the data are not believed to be representative of a significantly large area. 


\section{Distribution of dissolved solids}

Dissolved-solids concentration of major anions and cations was calculated from analyses using the following equation: Dissolved solids $=$

$$
\mathrm{Ca}+\mathrm{Ma}+\mathrm{Na}+(0.4917)\left(\mathrm{HCO}_{3}\right)+\mathrm{SO}_{4}+\mathrm{Cl}+\mathrm{K}+\mathrm{Sr} \text {, }
$$
where the concentration of each component, calcium, $\mathrm{Ca}$; magnesium, Mg; sodium, $\mathrm{Na}$; bicarbonate, $\mathrm{HCO}_{3}$; sulfate, $\mathrm{SO}_{4}$; chloride, $\mathrm{Cl}$; potassium, $\mathrm{K}$; and strontium, $\mathrm{Sr}$; is in milligrams per liter $(\mathrm{mg} / \mathrm{L})$.

\section{Water-quality type}

The dissolved-solids composition of a water consists primarily of six major ions: the three cations - calcium, magnesium, and sodium; and the three anions - bicarbonate, sulfate, and chloride. Relative proportions of these cations and anions can be displayed on trilinear diagrams: Waters of similar ionic proportions, and thus of similar chemical character, plot near one another. Therefore, areas of chemically similar waters can be delineated on the trilinear diagrams. For the purposes of this study, each trilinear diagram is divided into seven areas as shown in the accompanying illustration.

Water quality in basin fill is characterized by dominant cations and anions in solution and is shown in the accompanying map. The explanation lists dominant cation(s) and anion(s) combinations mapped in each area. 


\section{References cited}

Baker, C. H., Jr., 1974, Water resources of the Curlew Valley drainage basin, Utah and Idaho: Utah Department of Natural Resources, Technical Publication no. 45, 91 p. Bedinger, M. S., Sargent, K. A., and Reed, J. E., 1984, Geologic and hydrologic characterization and evaluation of the Basin and Range Province relative to the disposal high-level radioactive waste--Part I, Introduction and guidelines: U.S. Geological Survey Circular 904-A, 67 p., [in press]. Bjorklund, L. J., and McGreevy, L. J., 1971, Ground water resources of Cache Valley, Utah and Idaho: State of Utah Department of Natural Resources Technical Publication no. 36, 72 p.

Burnham, W. L., Harder, A. H., and Dion, N. P., 1969, Availability of ground water for large-scale use in the Malad Valley - Bear River areas of southeastern Idaho--An initial assessment: U.S. Geological Survey Water Resources Open-File Report, $40 \mathrm{p}$.

Dion, N. P., 1969, Hydrologic reconnaissance of the Bear River Basin in southeastern Idaho: Idaho Department of Reclamation, State Reclamation Engineer, Water Information Bulletin no. $13,66 \mathrm{p}$. Mundorff, M. J., and Sisco, H. G., 1963, Ground water in the Raft River Basin, Idaho with special reference to irrigation use, 1956-1960: U.S. Geological Survey Water Supply Paper 1619CC, $18 \mathrm{p}$. 
Pluhowski, E. J., 1970, Hydrology of the upper Malad River Basin, southeastern Idaho: U.S. Geological Survey Water-Supply Paper $1888,89 \mathrm{p}$.

Seitz, H. R., and Norvitch, R. F., 1979, Ground-water quality in Bannock, Bear Lake, Caribou and part of Power Counties, southeastern Idaho: U.S. Geological Survey Water Resources Investigations 79-14, Open-File Report, 55 p.

Waddell, K. M., and Price, Don, 1972, Quality of surface water in the Bear River Basin, Utah, Wyoming, and Idaho: U.S. Geological Survey Hydrologic Investigations Atlas HA-417, scale $1: 500,000,2$ sheets.

Walker, E. H., Dutcher, L. C., Decker, S. O., and Dyer, K. L., 1970, Raft River Basin, Idaho-Utah as of 1966--A reappraisal of the water resources and effects of ground-water development: Idaho Department of Water Administration, Water Information Bulletin no. 19, 95 p. 